\title{
Palynological and Physicochemical Characterization of Honey in the Sudano-Guinean Zone of Cameroon
}

\author{
Dongock Nguemo Delphine ${ }^{1 *}$, Tchoumboue Joseph ${ }^{2}$ \\ ${ }^{1}$ Laboratory of Biodiversity and Sustainability Development, Department of Biological Sciences, University of \\ Ngaoundere, Ngaoundere, Cameroon \\ ${ }^{2}$ Laboratory of Animal Physiology, Department of Animal Production, University of Dschang, Dschang, \\ Cameroon \\ Email: "ddongock@uni-ndere.cm,dndongock@yahoo.fr
}

Received 20 March 2015; accepted 8 November 2015; published 11 November 2015

Copyright (C 2015 by authors and Scientific Research Publishing Inc.

This work is licensed under the Creative Commons Attribution International License (CC BY).

http://creativecommons.org/licenses/by/4.0/

(c) (i) Open Access

\section{Abstract}

The palynological and physico-chemical characterization of honey was investigated in the SudanoGuinean zone of Cameroon through the melissopalynology analysis. Results showed that honey with the dark amber color was the most represented. Sweet honey with less odour considered as pleasant highly predominate. The pH of honey is low and varies from 3.95 to 5.00; this ranking confirms the hypothesis that honey is from plant through visit of honeybees. The sugar content is very high ranging from $77.93 \%$ to $83.13 \%$; the mean value is $\mathbf{7 8 . 9 0 \%}$ and this value confirms that the honey is floral honey. The density value ranges from 1.39 to 1.43 and does not exceed the average standard $\left(1.39\right.$ to 1.44 at $\left.20^{\circ} \mathrm{C}\right)$. Water contents correspond to the standards norms. For free acidity, the highest value is $48.68 \pm 0.28$. There is a low positive correlation $(r=0.2)$ between free acidity and the $\mathrm{pH}$ of honey. Pollen analysis of honeys led to the identification of 41 pollen species belonging to 25 families. The highly represented families are Asteraceae and Myrtaceae. Two thirds of honey is monofloral and characteristics of three dominant species: Nymphaea maculata, Terminalia avicennioides and Syzygium guineense. The pollens of Syzygium guineense are present in all honey samples analysed.

\section{Keywords}

Honey, Melissopalynology, Palynological Analysis, Physicochemical Analysis, Cameroon

\footnotetext{
${ }^{*}$ Corresponding author.
}

How to cite this paper: Delphine, D.N. and Joseph, T. (2015) Palynological and Physicochemical Characterization of Honey in the Sudano-Guinean Zone of Cameroon. Food and Nutrition Sciences, 6, 1339-1350. 


\section{Introduction}

Beekeeping is an old practice of the agricultural production system in the world and particularly in sub-Saharan Africa [1] [2]. Formerly based on harvesting honey in the wild, man consecrated his time on the rearing of bees like other animal species. Apicultural activities have undergone evolution through numerous scientific investigations [3]-[7]. The researchers like Spore [8], Tsafack [9], Abongu [10], Tchoumboue et al. [1], Prandin [11] and Adey [12] have demonstrated that beekeeping is not only the bearer of symbols, but it is also seen as source of food and income for developing countries. Indeed, beekeeping through its products provides means for sustainable existence. Honey is one of the oldest sweetening agents and is defined as the natural substance produced by Api smellifera bees from the plant nectar, from secretions of living parts of the plants, or from excretions of plant sucking insects on the living part of plants [13]. Honeybees collect, transform and combine this with specific substances of their own, and then store and leave it in the honeycomb to ripe and mature [14]. Honey from honeybees has significant nutritional and medicinal benefits. It is a rich source of readily available sugars, organic acids, various amino acids and in addition source of many biologically active compounds [15].

Organoleptical properties, physicochemical attributes and pollen spectrum are the main criteria for honey classification. Their measurement is comparatively simple and it provides a good information value [13]. The physicochemical parameters of natural honeys, such as moisture, diastase, sugars and HFM contents, acidity and specific conductivity, are strictly defined and constitute the quality indicators which characterize individual honey varieties [16]. Variations in nectar content, together with other factors such as climatic conditions, soil type, beekeeper activities and such, contribute to the existence of different types of honeys [17]. Differences in their composition also mean differences in the organoleptic and nutritional properties of the honey [13]. Honey is also compatible to a wide variety of products since its composition is characteristic of its botanical origin, age and storage conditions and transparency or clarity of honey depends on the amount of suspended particles such as pollen [18]. Bees forage different plants; thus, honey is always a mixture of several sources. However, in food control, pollen analysis is very efficient for the differentiation of honeys produced in distinctly different geographical and climatic areas [13].

Cameroonian Adamawa is one of the zones of high honey production; however, very few studies have been carried out to determine the quality of the honey produced [19] [20] [22]-[24] [31]. This work aimed to define some physicochemical and palynological characteristics of honey in the Adamawa region of Cameroon.

\section{Material and Methods}

\subsection{Geoclimatic Characteristics of the Study Zone}

Data on palynological and physicochemical characteristics of honeys were collected in the Cameroonian Adamawa Region situated between latitude $6^{\circ} \mathrm{N}$ and $8^{\circ} \mathrm{N}$ and longitude $10^{\circ} \mathrm{E}-16^{\circ} \mathrm{E}$, in the Sudano-guinean zone with an altitude of (900 to $13000 \mathrm{~m}$ ) (Figure 1). The soils are basaltic and ferralitic. The climate is SudanoGuinean with a long rainy season which runs from April to October and a short dry season from November to March. Rainfall varies from 1500 to $2000 \mathrm{~mm}$. The annual mean temperature is $22^{\circ} \mathrm{C}$ (minimum $10^{\circ} \mathrm{C}$ in January and maximum $35^{\circ} \mathrm{C}$ in March). Mean relative humidity is about $70 \%$ with an annual insolation of 2500 hours. The vegetation is a made up of shrub and woody savanna, Stylosanthes sp., Daniellia oliveri and Lophira lanceolata predominates, gallery forest is also present [25]. It is a transition zone between the forest in the south and the woody savanna in the north of Cameroon. Many rivers are present such as Djerem, Vina, Mbere and Benue.

The population of Adamawa is estimated at about 750,000 inhabitants, that is 11.8 inhabitants per $\mathrm{km}^{2}$. The main tribes are the Mboum and Dourou in Vina, the Gbaya, Mbila and Tikar in Djerem; the Koutine and NyemNyem in Faro and Deo; the Mboum and Gbaya in Mbere; Kaka and the Tikar in Mayo Banyo. The Bororos, Fulani and Hausa are disseminated throughout the region. The breeding of large and small livestock, agriculture and fishing are the main activities of the population. Agriculture concerns principally maize, cassava, sweet potato, yams and groundnuts where the greeted quantity is largely for subsistence populations.

\subsection{Collection of Honey Sample}

A total of 35 honey samples were collected in 2009 from beekeepers in three divisions belonging to the study zone. Among which 12 from Mbere, 03 from Djeremand 20 from Vina divisions. Honey was extracted by pressing. 


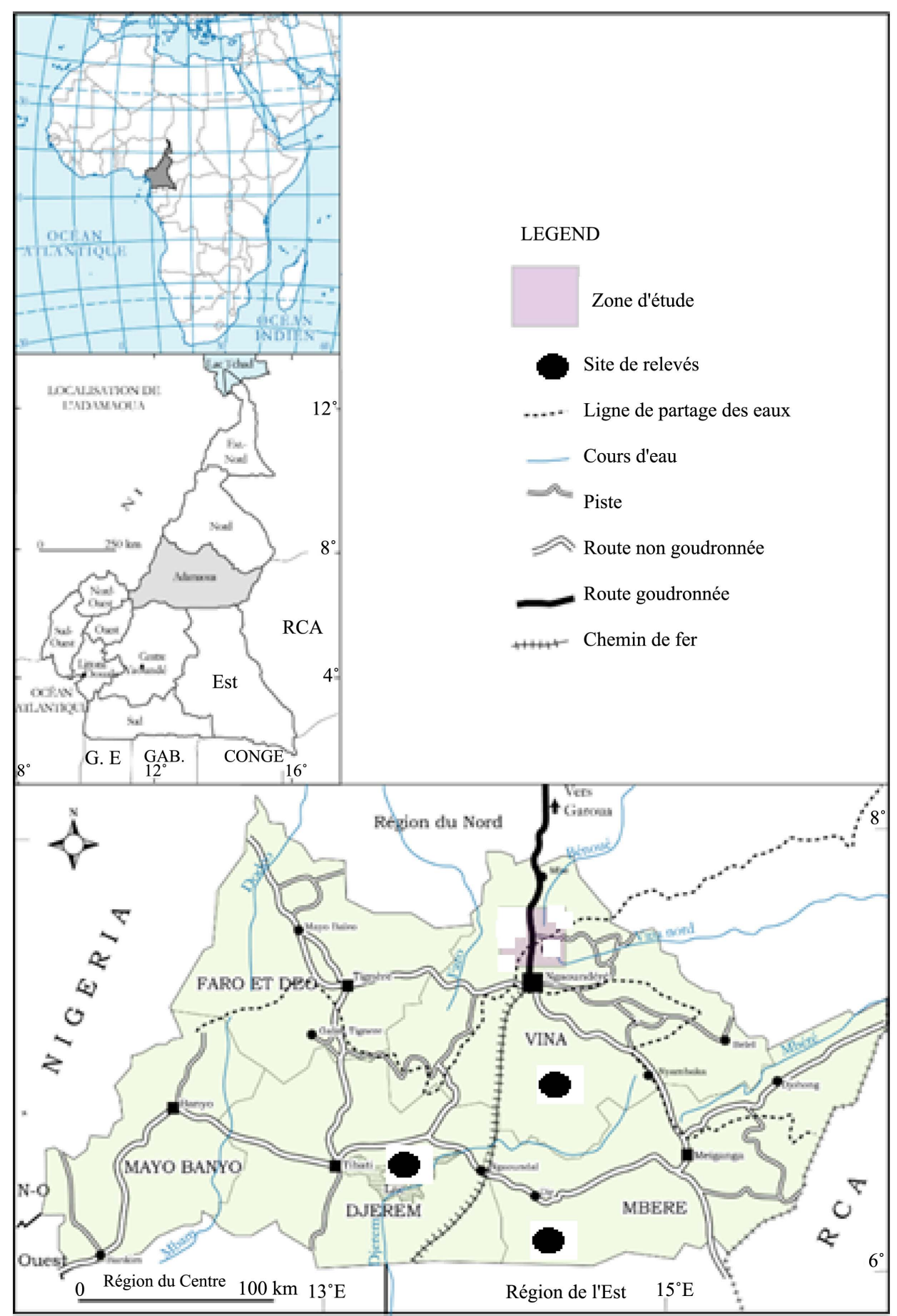

Figure 1. Study zone.

\subsection{Organoleptic Analysis}

Organoleptic characteristics were carried on 35 honey samples, they were based on colour, falvour and odour of the honey. The method used by Mutsaers [26], was used on a panel of 25 people to evaluate the taste and odour of the honey samples. It consisted of a visual observation and a taste test. Honey colors were determined by spectrophotometry as Proposed by Gonnet [27], Clark [28] and Biochrom [29]. The principle consist to measure the optic density of honey samples of wavelengths between 570 and $590 \mathrm{mn}$. 


\subsection{Pollen Spectrum of Honey}

Pollen spectrum were carried on 10 honey samples out of the 35 honey samples collected. Analysis were conducted according to the method of Bogdanov et al. [30]. Pollen grains of plants were grouped into four classes according to their percentage in honey samples. The following terms were used to estimate the pollen grain frequencies: "very frequent" for grains constituting more than $45 \%$ of the total; "frequent" for grains constituting $16 \%-45 \%$ of the total; "rare" for grains constituting 3\% - 15\% of the total; "sporadic" for grains constituting less than $3 \%$. The following terms are used for frequency classes: "predominant pollen" (more than $45 \%$ of the pollen grains counted); "secondary pollen” (16\% - 45\%); “important minor pollen” (3\% - 15\%); minor pollen” (less than 3\%).

\subsection{Physico-Chemical Properties}

Physico-chemical properties were carried out on 35 honey samples collected from beekeepers. Honey samples were analysed through the International Honey Commission (IHC) methods proposed by Bogdanov [31]. The physico-chemical characteristics were based on the total sugars, water content, $\mathrm{pH}$, free acidity and density.

\subsubsection{Determination of $\mathrm{pH}$}

$10 \mathrm{~g}$ of honey sample was dissolved in $75 \mathrm{ml}$ of carbon dioxide-free water in a $250 \mathrm{ml}$ beaker. It was stirred with the magnetic stirrer, the $\mathrm{pH}$ electrodes were immersed in the solution and the $\mathrm{pH}$ read.

\subsubsection{Determination of Free Acidity}

$10 \mathrm{~g}$ of honey sample was dissolved in $75 \mathrm{ml}$ of carbon dioxide-free water in a $250 \mathrm{ml}$ beaker. It was stirred with the magnetic stirrer, the $\mathrm{pH}$ electrodes were immersed in the solution. The Titrate with $0.1 \mathrm{M} \mathrm{NaOH}$ to $\mathrm{pH} 8.30$. The readings were recorded to the nearest $0.2 \mathrm{ml}$ when using a $10 \mathrm{ml}$ burette and to $0.01 \mathrm{ml}$ if the automatic titrator has sufficient precision. The results were express as follows: $\mathrm{A}=\left(\mathrm{C}_{\mathrm{NAOH}} \times \mathrm{V}_{\mathrm{NAOH}}\right) / \mathrm{M}$. $\mathrm{A}=$ honey acidity in millimoles acid $/ \mathrm{kg}$ honey; $\mathrm{C}=$ concentration of $\mathrm{NAOH}$ millimoles $/ \mathrm{ml} ; \mathrm{V}=$ volume of $\mathrm{NAOH}$ in $\mathrm{ml} ; \mathrm{M}=$ masse of honey in kg.

\subsubsection{Determination of Total Sugar and Water Content}

The total sugar and water content of honey was determined using a refractometer 107 REF 0\% - 90\% Brix model. Some drops of honey were deposited on the inner prism of the refractometer. Two measurements on each specimen and three determinations on each sample was made. The room temperature was registered using an electronic the rmohygrometer. The data obtained was corrected following the correction values of the reference temperature of $20^{\circ} \mathrm{C}$.

\subsubsection{Determination of the Density}

The density of the honey was obtained by comparing the mass and the volume of honey measured in a tube of $250 \mathrm{ml}$. In effect, the tube is filled with the previously weighed honey and then weighed on a precise scale. Four measures on each honey sample was carried out. The density was obtained by using the formula: $d=m / v$. $(d=$ density, $\mathrm{m}=$ mass, $\mathrm{v}=$ volume).

\subsection{Statistical Analyses}

Descriptive statistics methods (frequency, average, and percent) was used to analyses data in Excel. The correlation " $r$ " and the variance were calculated at a range of 5\% using the XLSTAT.

\section{Results and Discussion}

\subsection{Organoleptic Characteristics}

The organoleptic characteristic of honey shows that those with average sugar and with odour considered as pleasant is highly predominates. Honey with smoke odour is less represented. It is established that honey with smoke odour is due to harvesting with much smoke and heat, this gives an unpleasant taste [32]. Smoke also deteriorates the quality of honey. It is therefore important to sensitise and train beekeepers to use more efficient extraction methods that guarantee the quality of honey. 


\subsection{Color of Honey}

Three colors of honey were recorded in the zone (Table 1). Dark amber color is the most represented (66.7\%), followed by clear amber (22.91\%) and amber (10.41\%). Honey of Adamawa zone of Cameroon are less diversify in color compared to the western highland region in the same country where six colors were identified [33] and in the Ondo State of Nigeria with fourth color [34]. The work of Mutsaers [26], Kayode and Oyeyemi [34]) in Nigerian honey and Dongock et al. [33] in the Sudano-Guinean highlands of West Cameroon have also shown that dark amber or dark brown honey were the most represented color. This result is however in contrary to the research of Mbofung et al. [21] on the Adamawa honey where it is the clear amber color that predominates. Generally honey color reflects the melliferous flora harvested by bees which vary according to the seasons and to a lesser extent the harvesting technics and the treatment of honey.

\subsection{Physicochemical Characteristics of Honeys}

The physicochemical characteristics of honey samples were presented in Table 2.

\subsection{1. $\mathrm{pH}$}

According to the Codex Alimentarius Commission Standards [35], honeys whose $\mathrm{pH}$ is within the range of 3.5 to 4.5 are mainly from the plant visited by honeybees. It is the case of all the analysed samples of Vinaexcept 21. According to Persano-Oddo [36], flower honey often have low pH (3.3 à 4.6). Honey dew because of their high salt content with neutralising effect averagely has a higher $\mathrm{pH}$ value (4.2 à 5.5). These results confirm that the honeys analysed are from plants visited by bees. As indicated by Bogdanov et al. [37], honey from flowers have low value of $\mathrm{pH}(3.3$ - 4.6). These results are in accordance with those of Mbogning et al. [22] in the West and Adamawa region of Cameroon; Szczesna et al. [38] in Poland; Xesús Feá et al. [13] Portugal; Kombo [19] In the Adamawa region of Cameroon; Chefrour et al. [15] in Algeria and Kayode and Oyeyemi [34] in Nigeria. The $\mathrm{pH}$ values are high in the Mbere and Djerem site located between 4.27 and 5.0 indicate that it is about a honey of honeydew [35]. Moreover, honey with a low pH of about 3.5 like sample 18 in Vina is regarded as fragile product for the preservation [15].

\subsubsection{Sugars Content}

The sugar content of the honeys analysed ranged from $77.93 \%$ to $83.13 \%$, the mean value is $78.90 \%$. According to the estimates of Le Codex [39] flower honey can have (g/100g) sugar content corresponding to 60 , and 65 for honey dew. This parameter confirms that the honey samples studied were floral honey. Bogdanov et al. [37] also noted that the total sugar for floral honey was higher and ranges between 61.5 and 82.5 . The percentages of total sugar are however higher than those obtained in Poland [38] and in Portugal [13]. The total sugar contents (79.69\%) and also $\mathrm{pH}(4.59)$ are significantly higher $(\mathrm{P}<0.05)$ for honey from Mbere. On the other hand, honey from Vina (19.18\%) and Djerem (19.55\%) have a higher water contents. There is a positive correlation $(r=0.97)$ between the total sugar content and water in honey samples.

\subsubsection{Density}

The density values ranged from 1.39 to 1.43 in the study zone. From all honey samples analysed, the values did not exceed the average standard $\left(1.39\right.$ to 1.44 at $\left.20^{\circ} \mathrm{C}\right)$. The $\mathrm{pH}$ values and the density of honey in the three sites are comparable and they are closer to those of Chefrour et al. [15] in the North East of Algeria.

\subsubsection{Water Content}

Water content, a parameter related to the maturity degree, is an indicator of the mode of extraction of honey and

Table 1. Distribution of interviewsin function of honey colour.

\begin{tabular}{ccccc}
\hline \multirow{2}{*}{ Departments } & \multicolumn{3}{c}{ Honey colours (\%) } & Total \\
\cline { 2 - 4 } & Amber & Clear amber & Dark amber & 100 \\
Mbere & 12.5 & 25.0 & 62.5 & 100 \\
Vina & 12.5 & 37.5 & 50.0 & 87.5 \\
Djerem & 6.2 & 6.2 & 100 \\
\hline
\end{tabular}


Table 2. Physicochemical characteristics of honey in three divisions of Adamawa.

\begin{tabular}{|c|c|c|c|c|c|c|}
\hline Sites & No. & Total sugar (\%) & Water (\%) & $\mathrm{pH}$ & Free acidity & Density \\
\hline \multirow{12}{*}{ Mbere } & 1 & $79.40 \pm 0.53$ & $18.82 \pm 0.52$ & $4.27 \pm 0.0$ & $20.38 \pm 0.27$ & $1.41 \pm 0.01$ \\
\hline & 2 & $81.48 \pm 0.81$ & $17.11 \pm 0.65$ & $4.75 \pm 0.0$ & $10.66 \pm 0.56$ & $1.42 \pm 0.01$ \\
\hline & 3 & $79.73 \pm 0.42$ & $18.32 \pm 0.43$ & $4.55 \pm 0.0$ & $19.67 \pm 0.28$ & $1.40 \pm 0.01$ \\
\hline & 4 & $79.87 \pm 0.12$ & $18.28 \pm 0.36$ & $4.55 \pm 0.0$ & $31.06 \pm 0.55$ & $1.39 \pm 0.01$ \\
\hline & 5 & $79.60 \pm 0.40$ & $18.35 \pm 0.42$ & $4.62 \pm 0.0$ & $47.94 \pm 0.70$ & $1.41 \pm 0.01$ \\
\hline & 6 & $79.80 \pm 0.53$ & $18.23 \pm 0.58$ & $5.00 \pm 0.7$ & $41.44 \pm 0.71$ & $1.40 \pm 0.01$ \\
\hline & 7 & $78.93 \pm 0.42$ & $19.16 \pm 0.49$ & $4.75 \pm 0.0$ & $37.23 \pm 0.57$ & $1.40 \pm 0.01$ \\
\hline & 8 & $78.80 \pm 0.20$ & $19.19 \pm 0.44$ & $4.53 \pm 0.01$ & $41.09 \pm 1.13$ & $1.40 \pm 0.01$ \\
\hline & 9 & $78.20 \pm 0.20$ & $19.57 \pm 0.10$ & $4.58 \pm 0.01$ & $29.28 \pm 0.0$ & $1.41 \pm 0.01$ \\
\hline & 10 & $78.47 \pm 0.23$ & $19.50 \pm 0.06$ & $4.51 \pm 0.01$ & $28.41 \pm 0.55$ & $1.41 \pm 0.01$ \\
\hline & 11 & $83.13 \pm 0.42$ & $15.92 \pm 0.35$ & $4.47 \pm 0.01$ & $8.48 \pm 0.71$ & $1.43 \pm 0.01$ \\
\hline & 12 & $78.87 \pm 0.64$ & $19.18 \pm 0.55$ & $4.52 \pm 0.0$ & $43.22 \pm 0.28$ & $1.40 \pm 0.01$ \\
\hline \multirow[t]{11}{*}{ Mean } & & $79.69 \pm 0.44$ & $18.47 \pm 1.06$ & $4.59 \pm 0.18$ & $31.20 \pm 13.55$ & $1.41 \pm 0.01$ \\
\hline & 13 & $77.93 \pm 0.12$ & $19.91 \pm 0.50$ & $4.36 \pm 0.0$ & $9.92 \pm 0.0$ & $1.40 \pm 0.0$ \\
\hline & 14 & $76.80 \pm 0.20$ & $21.42 \pm 0.64$ & $4.22 \pm 0.01$ & $15.58 \pm 0.57$ & $1.40 \pm 0.0$ \\
\hline & 15 & $78.33 \pm 0.50$ & $19.81 \pm 0.59$ & $4.29 \pm 0.01$ & $17.05 \pm 0.0$ & $1.40 \pm 0.0$ \\
\hline & 16 & $78.90 \pm 0.30$ & $19.17 \pm 0.46$ & $4.45 \pm 0.0$ & $12.01 \pm 0.03$ & $1.42 \pm 0.0$ \\
\hline & 17 & $78.86 \pm 0.35$ & $19.18 \pm 0.47$ & $4.14 \pm 0.0$ & $13.36 \pm 0.28$ & $1.43 \pm 0.0$ \\
\hline & 18 & $78.87 \pm 0.15$ & $19.18 \pm 0.43$ & $3.39 \pm 0.0$ & $10.73 \pm 0.83$ & $1.41 \pm 0.0$ \\
\hline & 19 & $78.97 \pm 0.21$ & $19.15 \pm 0.44$ & $4.19 \pm 0.01$ & $20.78 \pm 0.28$ & $1.42 \pm 0.0$ \\
\hline & 20 & $79.77 \pm 0.15$ & $18.50 \pm 0.04$ & $4.55 \pm 0.01$ & $21.76 \pm 0.0$ & $1.40 \pm 0.0$ \\
\hline & 21 & $79.13 \pm 0.31$ & $18.88 \pm 0.47$ & $5.58 \pm 0.0$ & $21.79 \pm 0.28$ & $1.40 \pm 0.0$ \\
\hline & 22 & $77.87 \pm 0.31$ & $20.19 \pm 0.54$ & $4.57 \pm 0.0$ & $28.81 \pm 0.0$ & $1.40 \pm 0.0$ \\
\hline \multirow[t]{10}{*}{ Vina } & 23 & $78.73 \pm 0.23$ & $19.21 \pm 0.45$ & $4.61 \pm 0.01$ & $47.43 \pm 0.28$ & $1.40 \pm 0.0$ \\
\hline & 24 & $78.47 \pm 0.42$ & $19.50 \pm 0.10$ & $4.59 \pm 0.01$ & $41.14 \pm 0.28$ & $1.40 \pm 0.0$ \\
\hline & 25 & $77.67 \pm 0.31$ & $20.24 \pm 0.54$ & $4.61 \pm 0.01$ & $28.24 \pm 0.70$ & $1.40 \pm 0.0$ \\
\hline & 26 & $79.40 \pm 0.20$ & $18.59 \pm 0.05$ & $4.40 \pm 0.01$ & $45.97 \pm 0.28$ & $1.41 \pm 0.0$ \\
\hline & 27 & $78.80 \pm 0.62$ & $18.97 \pm 0.55$ & $4.75 \pm 0.0$ & $14.79 \pm 0.57$ & $1.40 \pm 0.0$ \\
\hline & 28 & $79.60 \pm 0.20$ & $18.54 \pm 0.10$ & $4.41 \pm 0.02$ & $20.86 \pm 0.28$ & $1.40 \pm 0.0$ \\
\hline & 29 & $79.67 \pm 0.50$ & $18.33 \pm 0.45$ & $4.37 \pm 0.0$ & $18.98 \pm 0.28$ & $1.40 \pm 0.0$ \\
\hline & 30 & $79.93 \pm 0.23$ & $18.27 \pm 0.39$ & $3.95 \pm 0.01$ & $21.28 \pm 0.28$ & $1.39 \pm 0.0$ \\
\hline & 31 & $79.80 \pm 0.20$ & $18.30 \pm 0.38$ & $4.16 \pm 0.0$ & $16.50 \pm 0.28$ & $1.40 \pm 0.0$ \\
\hline & 32 & $79.93 \pm 0.42$ & $18.27 \pm 0.43$ & $4.28 \pm 0.0$ & $21.77 \pm 0.28$ & $1.40 \pm 0.0$ \\
\hline \multirow[t]{2}{*}{ Mean } & & $78.66 \pm 0.67$ & $19.18 \pm 0.82$ & $4.40 \pm 0.20$ & $31.20 \pm 13.55^{b}$ & $1.41 \pm 0.01^{\mathrm{a}}$ \\
\hline & 33 & $78.33 \pm 031$ & $19.54 \pm 0.08$ & $4.33 \pm 0.01$ & $41.66 \pm 0.56$ & $1.41 \pm 0.01$ \\
\hline \multirow[t]{2}{*}{ Djerem } & 34 & $78.80 \pm 0.20$ & $19.19 \pm 0.44$ & $4.56 \pm 0.01$ & $48.68 \pm 0.28$ & $1.42 \pm 0.01$ \\
\hline & 35 & $77.93 \pm 0.31$ & $19.91 \pm 0.54$ & $4.52 \pm 0.0$ & $43.72 \pm 0.28$ & $1.39 \pm 0.01$ \\
\hline Mean & & $78.36 \pm 0.43$ & $19.55 \pm 0.36$ & 4.47.0.12 & $22.85 \pm 0.52^{\mathrm{a}}$ & $1.41 \pm 0.0^{\mathrm{a}}$ \\
\hline
\end{tabular}


density. Analyzed honeys had values between $15.92 \%$ - 21.42\%. According to Gonnet [27], honey having water content higher than $18 \%$ is regarded as lower quality honey. This indicates that, some honey sample of our zone is not of good quality. Research on water contents in Poland honey by Szczesna et al. [38] and in Algeria by Chefrour et al. [15] therefore corresponds to the norms. They are however lower to those noted in the work of Kombo [19] and Mbogning et al. [22] in the West and Adamawa zone of Cameroon. The high water content is due to early harvesting or only to the hygroscopicity of honey [22]. The monoflora honeys of Nymphea maculata, Terminalia avicennioides and Syzygium guineense present water content values and $\mathrm{pH}$ of honey significantly higher than those observed by Makhloufi et al. [40] in Algeria for Eucalyptus and Citrus honey; this author confirm that there are no fixed limits for $\mathrm{pH}$ values, however this parameter may be used as an indication of the botanical origin. Values above 5.0 usually point to honeydew honey.

\subsubsection{Free Acidity}

The average of free acidity of honey samples is 32.93 with a range of $08.48-48.68$. The highest value was obtained in Djerem (48.68 \pm 0.28$)$, followed by Mbere $(47.94 \pm 0.70)$. A weak positive correlation $(r=0.2)$ between free acidity and $\mathrm{pH}$ of honey was discover. This signify that free acidity and $\mathrm{pH}$ evolved in the same direction. The values of free acidity is situated at the same range as those of Xesús Feá et al. [13] in the honeys of Portugal, however they are higher to those of Szczesna et al. [38] in Poland and of Chefrour et al. [16] in northern Algeria. The acidity of the honey is due to a large number of organic acids that it contained therein. Free acidity may be explained by taking into account the presence of organic acids, which are proportional to the corresponding lactones, or internal esters, and some inorganic ions such as phosphate or sulphate [13]. Variation in free acidity among different honeys can be attributed to floral origin or to variation because of the harvest season [13] [22]. In the Codex Alimentarius [14] Standard directives, the maximum water content value of pure floral honey is less than $20 \%$ in general. Variation in free acidity among different honeys can be attributed to floral origin or to variation because of the harvest season [15]. The botanic origin has also a very high influence on the quality of honey and all its investigated characteristics; different beehive types, origin of queen bees. The material of beehives have an influence on the development of bee diseases and the quality of honey [14].

\subsection{Spectrum of Honey Plants}

The spectrum of plant species whose pollen grains are identified in honey samples is summarized in Table 3. 41melliferous plants belonging to 25 families were identified. The highest represented families are Asteraceae and Myrtaceae with an average of fourth species, followed by Euphorbiaceae, Caesalpiniaceae, Mimosaceae and Anacardiaceae represented by three plants each. The other families are less represented with one or two species (Combretaceae, Musaceae, Bignoniaceae, Lauraceae, Verbenaceae). The number of species identified in the honey sample of this region were less compared to the work of Kayode and Oyeyemi [34] in the Ondo State (Nigeria); 58 pollen types were identified. The most frequently represented families were Fabaceae with 14 taxa and Euphorbiaceae with 11 taxa. In Algeria, Chefrour et al. [15] identified sixty five pollen types from 28 families where three families (Asteraceae, Rosaceae and Apiaceae) are the most represented. The Fabaceae and Rosaceae families provided the greatest number of pollen types with seven species in Portugal [13].

\subsection{Frequency of Beeplants}

After identification, it stands out that $60 \%$ of honey are monofloral and $40 \%$ multifloral. These results are in accordance with those of Dongock et al. [42] in the Western highlands of Cameroon. They are however contrary with the observations made by Chefrour et al. [15] who noted that all honeys from the north-East of Algerian were polyfloral. The monofloral honey are characteristics of three species: Nymphaea maculata, Terminalia avicennioides and Syzygium guineense with their pollens present in 30\%, 20\% and 10\% of honey samples respectively. All honey samples analysed contain minor pollens, $90 \%$ of them contain the important minor pollen, $50 \%$ secondary pollen and $60 \%$ dominant pollens. The dominant plants represents $07.14 \%$ of total melliferous plants. Nymphaea maculata is strongly represented in three samples of honey, it is usually accompanied by Tithonia diversifolia, Delonix regia, Daniella oliveri and Syzygium guineense. Syzygium guineense honey also contains pollen of Nymphea maculata, Eucalyptus camaldulensis, Delonix regia and Daniella oliveri. In the honey samples, Terminalia avicennioides is associated among to Syzygium Guinean, Vitellaria paradoxa, Stylosenthes guineense, Mangifera indica and Lophira lanceolata. 
Table 3. The spectrum of melliferous plants: (legend: $\mathrm{D}=$ predominant pollen $(>45 \%)$; $\mathrm{A}=$ secondary pollen $(16 \%-45 \%)$; $\mathrm{S}=$ important minor pollen $(3 \%-15 \%)$; $\mathrm{I}=$ minor pollen $(<3 \%)$ ).

\begin{tabular}{|c|c|c|c|c|c|c|c|c|c|c|}
\hline \multirow{3}{*}{ Families and scientific names } & \multicolumn{10}{|c|}{ Origin and number } \\
\hline & \multicolumn{4}{|c|}{ Mbere honey } & \multicolumn{3}{|l|}{ Djerem honey } & \multicolumn{3}{|c|}{ Vina honey } \\
\hline & 1 & 2 & 3 & 4 & 5 & 6 & 7 & 8 & 9 & 10 \\
\hline \multicolumn{11}{|l|}{ ANACARDIACEAE } \\
\hline Lannea kerstingii & & & & & & & I & & & I \\
\hline Mangifera indica & I & $\mathrm{S}$ & $\mathrm{I}$ & I & I & & & & & \\
\hline Sclerocarya birrea & I & I & I & I & S & & & & & \\
\hline \multicolumn{11}{|l|}{ APOCYNACEAE } \\
\hline Voacanga africana & I & & I & I & & & I & I & I & \\
\hline \multicolumn{11}{|l|}{ ASTERACEAE } \\
\hline Ageratum conyzoides & $\mathrm{S}$ & I & & & I & I & & I & & \\
\hline Bidens pilosa & I & & & & I & & & & I & I \\
\hline Tithonia diversifolia & I & & & & & I & I & $\mathrm{S}$ & I & I \\
\hline Acacia sieberiana & I & & & I & I & & I & I & & I \\
\hline Vernonia sp. & I & & & & & I & I & I & & I \\
\hline \multicolumn{11}{|l|}{ BIGNONACEAE } \\
\hline Jacaranta ovalifolia & & & & & & & & I & & \\
\hline \multicolumn{11}{|l|}{ BOMBACACEAE } \\
\hline Bombax pentandrum & I & & & & I & I & I & & I & I \\
\hline \multicolumn{11}{|l|}{ CAESALPINIACEAE } \\
\hline Daniella oliveri & $\mathrm{S}$ & I & & & I & $\mathrm{S}$ & $\mathrm{S}$ & I & $\mathrm{S}$ & I \\
\hline Delonix regia & & & & & & $\mathrm{S}$ & I & $\mathrm{S}$ & I & A \\
\hline \multicolumn{11}{|l|}{ CAPPARIDACEAE } \\
\hline Capparis sp. & & & & & & I & & I & & \\
\hline \multicolumn{11}{|l|}{ CLUSIACEAE } \\
\hline Psorospermum febrifigum & & & & & & & & I & & \\
\hline \multicolumn{11}{|l|}{ COMBRETACEAE } \\
\hline Terminalia avicennioides & A & $\mathrm{D}$ & $\mathrm{S}$ & $\mathrm{D}$ & S & & I & I & & \\
\hline \multicolumn{11}{|l|}{ EUPHORBIACEAE } \\
\hline Euphorbia milii & & & & & & & I & I & & \\
\hline Euphorbia pulcherima & & & & & & & I & & & \\
\hline Manihot esculenta & I & I & & I & I & I & & & & \\
\hline \multicolumn{11}{|l|}{ FABACEAE } \\
\hline Crotalaria sp. & & & & & & I & I & I & I & I \\
\hline Stylosanthes guianensis & I & S & $\mathrm{S}$ & S & I & I & I & & I & I \\
\hline LAURACEAE & & & & & & & & & & \\
\hline
\end{tabular}




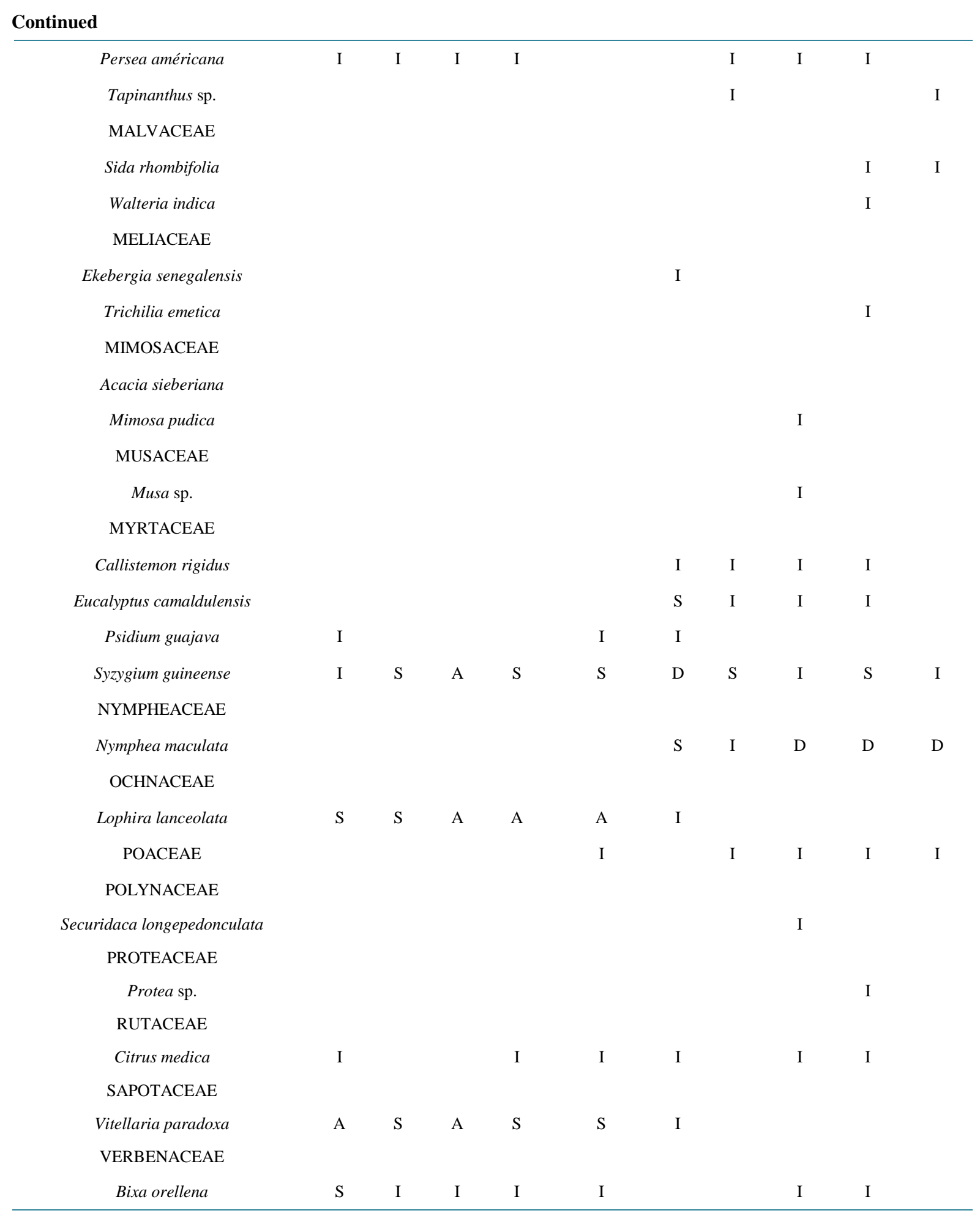

Secondary melliferous plants is represented by five species (Lophira lanceolate, Syzygium guineense, Terminalia avicennioides, Ittelaria paradoxa and Delonix regia), that is $06.5 \%$ of melliferous plants listed. Lophira lanceolate and Ittelaria paradoxa are the most represented with their pollen found respectively in three and two samples. Makhloufi et al. [40] noted that 34\% of honey samples contained 23 predominant and secondary pollen species. 
Important minor plants are a bit represented with $23.94 \%$ of foraged plants. The most important minor plants were Syzygium guineense and Daniella oliveri whose pollens are identified in five and four samples of honey respectively.

Minor melliferous plants are the most represented (79.1\%) in terms of number of species. The most common are represented by Voacanga aficana, Acacia sieberiana, Bombax pentandrum, Stylosenthes guineense and Bixa orellena whose pollens are found in $60 \%$ of honey samples. According to Louveaux et al. [43]) and Schweitzer [44], the identification of a pollen grain even isolated in honey can have very important consequences for the knowledge of it geographical origin. Syzygium guineense pollens are present in all honey samples analyzed. In Portugal Xesús Feá et al. [13] note that pollen grains of Eucalyptus sp. were found in all honey samples (100\%) of the same region. The only type of pollen present in almost all the samples was the Eucalyptus. Eucalyptus spp. is very characteristic plant species and good nectar sources, found throughout Algeria [41]. This species is a polliniferous plant which has a very broad surface of distribution. Eucalyptus originated from Australia but is cultivated in many regions of the world and can cause alterations to the local flora; flowering period extends for a very long period throughout the year. It is an advantage for the bees to exploit the flowers when other flowers are lacking [45]. However, in other country when other individual and blooming melliferous plants are abundant, Eucalyptus are less attractive to the bees [40] [46]-[48].

Most of the plants identified in the Western highlands of Cameroon [40] and at Bukavu [48] are also listed in our zone. However, species like Vocanga africana, Terminalia avicennioides, Hymenocardia acida, Lophira lanceolata, Sclerocarya birrea, and Securidaca longepedonculata are found specifically in Adamawa. The existence of specific plants can be of great interest in the labeling and geographic traceability of honey in the Adamawa. According to Lobreau-Callen and Damblon [46] and Lobreau-Callen et al. [49], the foraging strategy of honey can depend on several complementary factors: the production of flowers in the environment, the quality of pollen and nectar production, the competition among bees during the foraging activity. Many factors influence the number of pollen in honey. It is known that the pollen richness depends upon the pollen production of the plant, the weather conditions and the distance of the beehive to the flower field, the filtering by the bee's and consequently the pollen's diameter, and the mode of honey extraction [50].

\section{Conclusion}

The palynological characteristics of honeys show a predominance of monofloral honey. Though in the site there is a high diversity of melliferous species. The spectrum of melliferous plants is large and diverse in terms of the number of species with 41 in 25 families. The highly represented families are Asteraceae and Myrtaceae. Nymphaea maculata is much represented as predominant in honey. Secondary melliferous plants are represented by Lophira lanceolata, Syzygium guineense, Terminalia avicennioides, Delonix regia and Vitellaria paradoxa. The physicochemical characteristics of the honey samples analysed in this study generally were in agreement with the requirements of European Community Standards.

\section{References}

[1] Tchoumboue, J., Tchouamo, I.R., Pinta, I.J. and Njia, M.N. (2001) Caractéristiques socio-économique et techniques de l'apiculture dans les Hauts plateaux de l'Ouest du Cameroun. Tropicultura, 19, 141-146.

[2] UNAF (1997) Apithérapie: La science de l’abeille pour l'énergie et le bien-être. Paris, 80 p.

[3] Njia, M.N. (1998) Caractéristiques socio-économique et technique de l'apiculture dans les Hauts plateaux de l’Ouest Cameroun. Mémoire d'ingénieur Agronome. Option production animale, FASA, Université de Dschang, Cameroun, 75 p.

[4] Laflèche (1981) Les abeilles. Guide pratique de l'apiculteur amateur. 75 p.

[5] Da Costa Dórea, M., de Novais, J.S. and de Assis Ribeiro dos Santos, F. (2010) Botanical Profile of Bee Pollen from the Southerncoastal Region of Bahia, Brazil. Acta Botanica Brasilica, 24, 862-867. http://dx.doi.org/10.1590/S0102-33062010000300028

[6] Apimondia (2001) Apiculture en Afrique. Apiacta, 34-48.

[7] FAO (2004) Beekeeping and Sustainable Livelihoods. Diversification Bookled 1, Rome, 62 p.

[8] Spore (2007) Apiculture. Le miel des bonnes affaires. No. 128, CTA, 15 p.

[9] Tsafack, M.A.S. (2006) Une analyse de la production apicole dans les Départements de Boyo (Nord-Ouest Cameroun). Thèse de Master en Science et Agribusiness. FSEG-Université de Dschang, Cameroun, 137 p. 
[10] Abongu, L. (2001) Gender and Beekeeping in the North-West Province of Cameroon: Case of Localities under INADES. Formation Backup Action in Belo, Fundong, Kedjomketinguh and Mbengwi. Memoir of Ingenieur Agronome in Economy and Rural Sociology Option. FSEG-Université de Dschang, Cameroun, 101 p.

[11] Prandin, L., Pedrazzini, G. and Mutinelli, F. (2000) Beekeeping in Tanzania. Tropicultura, 18, 94.

[12] Adey, M. (1985) Nairobi Conference on Tropical Apiculture. Bee World, 66, 54-62. http://dx.doi.org/10.1080/0005772x.1985.11098825

[13] Feás, X., Pires, J., Estevinho, M.L., Iglesias, A. and De Araujo, J.P.P. (2010) Palynological and Physicochemical Data Characterisation of Honeys Produced in the Entre-Douro and Minho Region of Portugal. International Journal of Food Science and Technology, 45, 1255-1262. http://dx.doi.org/10.1111/j.1365-2621.2010.02268.x

[14] Codex Alimentarius (2001) Qualité du miel et normes internationales relatives au miel. Rapport de la Commission Internationale du miel, $16 \mathrm{p}$.

[15] Chefrour, C., Draiaia, R., Tahar, A., Kaki, Y.A., Bennadja, S. and Battesti, M.J. (2009) Physicochemical Characteristics and Pollen Spectrum of Some North East Algerian Honeys. African Journal of Food, Agriculture, Nutrition and Development, 9, 1276-1293. http://dx.doi.org/10.4314/ajfand.v9i5.45101

[16] Abou-Tarboush, H., Al-Kahtani, H. and EL-Sarrage, M. (1993) Floral Type Identification and Quality Evaluation of Some Honey Type. Food Chemistry, 46, 13-17. http://dx.doi.org/10.1016/0308-8146(93)90068-Q

[17] Anklam, E. (1998) A Review of the Analytical Methods to Determine the Geographical and Botanical Origin of Honey. Food Chemistry, 63, 549-562. http://dx.doi.org/10.1016/S0308-8146(98)00057-0

[18] Tchoumboue, J., Awah-Ndukum, J., Fonteh, F.A., Dongock, N.D., Pinta, J. and Mvondo Ze, A. (2007) PhysicoChemical and Microbiological Characteristics of Honey from the Sudano-Guinean Zone of West Cameroon. African Journal of Biotechnology, 6, 908-913.

[19] Kombo, P. (1989) Apiculture et miel dans la province de l’Adamaoua (Cameroun). Thèse de docteur vétérinaire, Université cheikh antadiop de dakar, Ecole inter états des sciences etmédecinevétérinaires, No. 48.

[20] Founadoudou (2007) Caractéristiques socio-économique et techniques de l'apiculture de la zone soudano-guinéenne de l’Adamaoua (Cameroun). Mémoire d'ingénieurs Agronome. Option Production animale. Université de Dschang, Cameroun.

[21] Mbofung, G., Tchuenguem Fohouo, F.-N., Boubar, O., Hemo, J.H. and Brückner, D. (2000) Characterization of Some Honeys from the Adamawa Cameroon Using Melissopalynological Methods. Biosciences Proceeding, 7, 108-120.

[22] Mbogning, E., Tchoumboue, J., Damesse, F., Sobze, M.S. and Canini, A. (2011) Caractéristiques physico-chimiques des miels de la zone Soudano-guinéenne de l'Ouest et de l'Adamaoua Cameroun. Tropicultura, 29, 168-175.

[23] Mbawala, A., Darman, R.D., Essia Ngang, J.-J., Tchuenguem Fohouo, F.-N. and Etoa, F.-X. (2002) Activité antimicrobienne de quelques miels d'origine variée de la savane guinéenne de l'Adamaoua camerounais. Cam. J. Biol. and Bioch Sc, 12, 8-17.

[24] Mbawala, A., Essia Ngang, J.-J., Darman, R.D., Tchuenguem Fohouo, F.-N. and Etoa, F.-X. (2002) Qualité microbiologique du miel vandu sur le marché de Ngaoundéré (Cameroun). Micob. Hyg. Ali., 14, 3-7.

[25] Letounzey, R. (1985) Notice de la carte phytogéographique du Cameroun au 1: 500000. 60 p.

[26] Mutsaers, M. (1997) Honey Harvesting and Processing Techniques in Relation to Beekeeping Methods and Types of Hive (Apis mellifera adansonii) in Nigeria. In: Sommeijer, M.J., Beetsma, J., Boot, W.J., Robberts, E.-J. and de Vries, R., Eds., Perspectives for Honey Production in the Tropics, NECTAR, Utrecht, 37-53.

[27] Gonnet, M. (1985) L’analyse des miels. Description de quelques méthodes de contrôle de la qualité. Bulletin Technique Apicole, 13, 17-36.

[28] Clark, M.A. (1995) Sugar and Sugar Products. Chapter 44, Subchapter 4 in "Official Methods of Analysis of AOAC International”, $88 \mathrm{p}$.

[29] Biochrom (2003) Technique: Spectrophotometry. Application Areas: Food and Drink, Anonyme.

[30] Bogdanov, S. and 21 Other Members of the International Honey Commission (1999) Honey Quality, Methods of Analysis and International Regulatory Standards: Review of the Work of the International Honey Commission. Mitteilungen aus Lebensmitteluntersuchung und Hygiene, 90, 108-125.

[31] Bogdanov, S. (2002) Harmonised Methods of the International Honey Commission. Swiss Bee Research Centre, FAM, Liebefeld.

[32] Anchling, F. (2007) La couleur du miel l’Abeille de France et l'apiculteur No. 942, 495-504.

[33] Dongock, N., Tchoumboue, J.D., Youmbi, E., Zango, P., Hamawa, Y. and Mapongmetsem, P.M. (2009) Floral Characteristics of Honey in the Sudano-Guineane Highland of West Cameroon. Sciences Agronomiques et Développement, 5, 23-30. 
[34] Kayode, J. and Oyeyemi, S.D. (2014) Physico-Chemical Study and Analysis of Pollen Grains in Some Commercial Honey Samples Found in Ondo State, Nigeria. International Journal of Basic and Applied Science, 3, 63-73.

[35] Codex Alimentarius Commission Standards (1981) Codex Standard for Honey. European Regional Standards, Volume III, FAO, Rome.

[36] Persano-Oddo, L. (1992) Instituto Zool. Agraria, Sezione Apicoltura, Via Leonida Rech 36, 00156 Roma.

[37] Bogdanov, S., Bieri, K., Gremaud, G., Iff, D., Känzig, A., Seiler, K., Stöckli, H. and Zürcher, K. (2004) Produits apicoles. 23 A Miel. Revus par le groupe d'experts "Produits apicoles”, 37 p.

[38] Szczesna, T., Rybak-Chmielewska, H., Was, E., Kachaniuk, K. and Teper, D. (2011) Characteristics of Polish Unifloral Honeys. I. Rape Honey (Brassica napus L.var. Oleifera). Journal of Apicultural Science, 55, 111-119.

[39] Codex Alimentarius Commission (1993) Revised Codex Standards for Sugars and Honey. CX 5/10.2, CL/14-SH, Viadelle Terme di Caracalla, Rome.

[40] Makhloufi, C., Kerkvliet, J.D., D’albore, G.R., Choukri, A. and Samar, R. (2010) Characterization of Algerian Honeys by Palynological and Physico-Chemical Methods. Apidologie, 41, 509-521. http://dx.doi.org/10.1051/apido/2010002

[41] Tucak, Z., Periškić, M., Škrivanko, M. and Konjarević, A. (2007) The Influence of the Botanic Origin of Honey Plants on the Quality of Honey. Original Scientific Paper.

[42] Delphine, D.N., Joseph, T. and Emmanuel, Y. (2012) Végétationmellifères du Cameroun. Edition Universitaire Européenne, 385 p.

[43] Louveaux, J., Maurizio, A. and Vorwohl, G. (1978) Methods of Melissopalynology. Bee World, 59, 139-154. http://dx.doi.org/10.1080/0005772X.1978.11097714

[44] Schweitzer, P., Nombré, I., Aidoo, K. and Boussim, I.J. (2013) Plants Used in Traditional Beekeeping in Burkina Faso. Open Journal of Ecology, 3, 354-358. http://dx.doi.org/10.4236/oje.2013.35040

[45] Barth, O.M. (2004) Melissopalynologie in Brazil: A Review of Pollen Analysis of Honeys, Propolis and Pollen Loads of Bees. Scientia Agricola, 61, 342-350.

[46] Lobreau-Callen, D. and Damblon, F. (1994) Spectre pollinique des miels de l'Abeille Apis mellifera L. (Hymenoptera, Apidae) et zone de végétation en Afrique occidentale tropicale et méditerranéenne. Grana, 33, 245-253. http://dx.doi.org/10.1080/00173139409429006

[47] Dongock, N.D., Tchoumboue, J., D’Albore, G.R., Youmbi, E. and Pinta, Y.J. (2007) Spectrum of Melliferous Plants Used by Apis mellifera adansonii in the Sudano-Guinean Western Highlands of Cameroon. Grana, 46, 123-128. http://dx.doi.org/10.1080/00173130701318459

[48] Bakenga, M., Bahati, M. and Balagizi, K. (2000) Inventaire des plantes mellifères de Bukavu et ses environs (Sud-kivu, Est de la République Démocratique du Congo). Tropicultura, 18, 89-93.

[49] Lobreau-Callen, D., Darchen, R. and Le Thomas, A. (1986) Apport de la palynologie a la connaissance des relations abeilles/plantes en savanes arborées du togo et du bénin. Apidologie, 17, 279-306. http://dx.doi.org/10.1051/apido:19860401

[50] Von der Ohe, W. (1994) Unifloral Honeys: Chemical Conversion and Pollen Reduction. Grana, 33, $292-294$. http://dx.doi.org/10.1080/00173139409429013 